\title{
PENGARUH TUNNELLING INCENTIVE DAN DEBT CONVENANT TERHADAP TRANSFER PRICING YANG DIMODERASI OLEH TAX MINIMIZATION
}

\author{
Astuti Mintorogo \\ Universitas Pancasila \\ msmintorogoa@gmail.com \\ Syahril Djaddang \\ Universitas Pancasila
}

\begin{abstract}
Abstrak
Penelitian ini betujuan untuk menguji kebenaran terhadap pengaruh tunnelling incentive dan debt convenant terhadap keputusan transfer pricing yang dimoderasi oleh tax minimization. Pengukuran tunnelling incentive melalui jumlah kepemilikan saham, debt convenant diukur menggunakan strategi hutang dengan DER, dan tax minimization diukur menggunakan beban pajak dengan persentase laba kena pajak di masing-masing perusahaan manufaktur.

Sample yang digunakan berbasis data skunder, dari Bursa Efek Indonesia sejak tahun 2015-2018. Metode Purposive sampling 60 data laporan keuangan dengan jumlah 15 perusahaan manufaktur tekstil. Tunnelling incentive berpengaruh terhadap keputusan transfer pricing sedangkan debt convenant tidak berpengaruh terhadap keputusan transfer pricing. Tax minimization tidak memoderasi pengaruh antara tunnelling incentive dan debt convenant terhadap keputusan transfer pricing.

Dengan memperbanyak sampel khususnya di negara-negara Asia dapat membuat penelitian ini lebih berkembang dan sebagai bahan pertimbangan bagi para investor yang ingin berinvestasi, sebaiknya melakukan pengecekan ulang laporan pada keuangan yang ditebitkan oleh perusahaan, pada saat mengambil keputusan untuk berinvestasi.
\end{abstract}

Key Words : tunnelling incentive, tax minimization, debt convenant, transfer pricing.

\section{PENDAHULUAN}

World Trade Organization atau yang dahulu kita kenal sebagai GATT semakin mendorong perusahaan multinasional dalam bertransaksi. Meningkatnya transaksi antar negara ini, hamper meniadakan batas anatara negara yang satu dengan negara yang lainnya. Hal ini juga berpengaruh terhadap jumlah modal yang ditanam oleh negara yang satu dengan negara yang lainnya, akibatnya arus perdagangan inernasional semakin meningkat. Dari fenomena tersebut kita dapat melihat potensi penerimaan dari kegiatan tersebut. International trade transactions sebagian besar melibatkan multinational company baik dalam satu group maupun dalam intra group dan semakin komplek transaksi yang terjadi, tidak hanya dalam mengimplikasikan jasa, barang modal, dan harta tak bergerak. Dalam grafik di bawah ini dapat dilihat mengenai perkembangan laba atau tingkat penghasilan yang terjadi dari transaksi multinational company. Data diambil dari tahun 2012-2016 sebagai tolakan ukuran untuk melihat transaksi yang terjadi

Jurnal Akuntansi dan Auditing Volume 16/No. 1 Tahun 2019: 30-40 



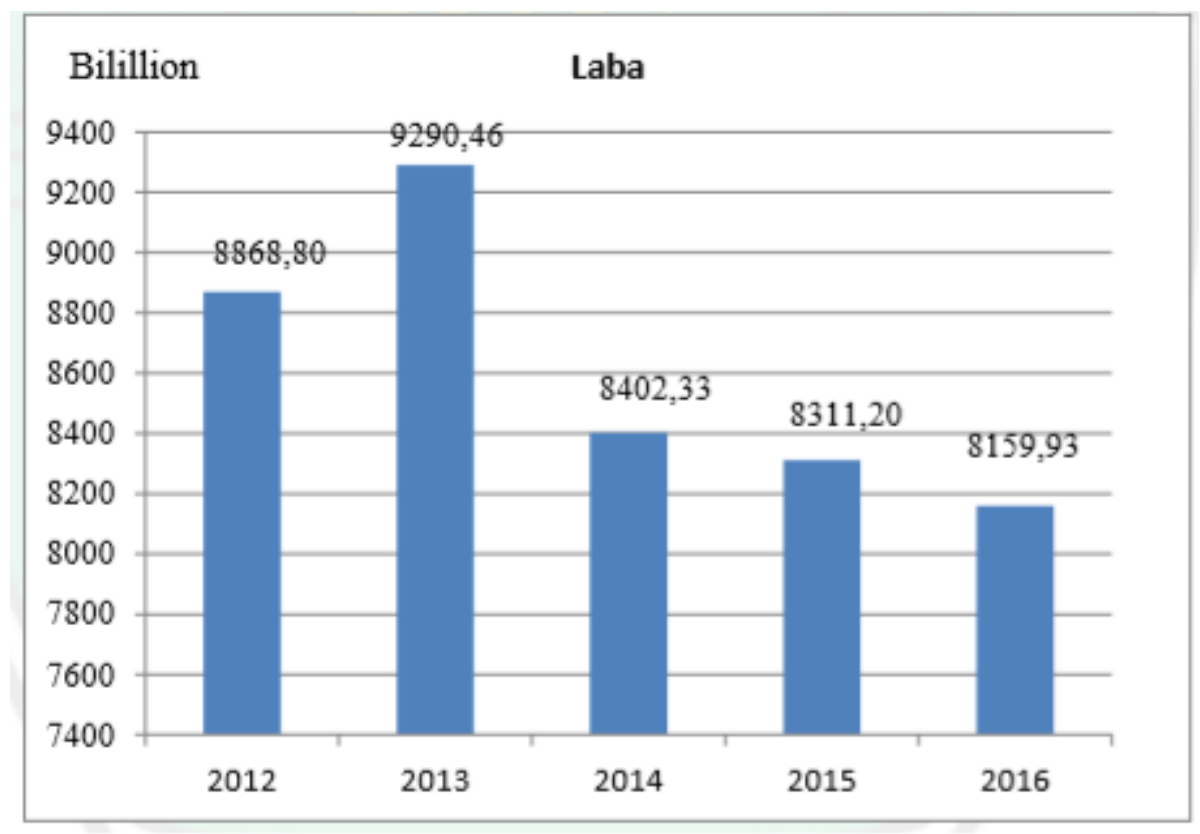

Dari fenomena di atas yang mendasari dalam penelitian ini, terlihat dari tahun 2014-2016 yang mengalami penurunan tajam dalam artian perusahaan tersebut mengalami kerugian. Hal ini sangat tidak mungkin sekali menginggat perusahaan multinasional yang memiliki banyak sekali transaksi dan seharusnya memberikan keuntungan. Hal tersebut diatas pasti didorong oleh sesuatu yang dapat menyebabkannya. Dan salah satunya strategi dari perusahaan multinational company yaitu dengan melakukan transfer pricing. Sehingga walaupun terlihat mengalami kerugian, namun yang terjadi adalah memperoleh keuntungan yang besar yang tidak dapat terlihat. Dengan memperkecil laba maka pembayaran pajak yang seharusnya terjadi menjadi dapat lebih kecil dari seharusnya. Hal ini yang mendasari lebih lanjut untuk penelitian ini bahwa disamping pajak, tunnelling incentive, tax minimization, debt convenant dapat mempengaruhi suatu perusahaan multi nasional dalam mengambil keputusan dalam melakukan transfer pricing.
Pemegang saham minoritas perusahaan memperoleh kerugian ketika harga transfer memberikan keuntungan kepada parent company atau shareholders, pengendali. Tunnelling diimplementasikan sebagai pengiriman berupa transfer ke parent company dari pihak yang bersangkutan dan pembagian dividen. Transaksi pihak terkait dengan bertujuan menjalankan pembayaran dividen karena pengalokasian dividen kepada parent company dan shareholders minoritas diwajibkan bagi perusahaan yang terdaftar di Bursa Efek Indonesia. Sebagai dasar "UU No. 36 Tahun. 2008 tentang Pajak Penghasilan Pasal 18 ayat". (4) terkait adanya hubungan antara Wajib Pajak Badan dikarenakan kepemilikan dan modal saham yang dikuasai suatu badan lainnya sebesar lebih dari $25 \%$, atau badan yang memiliki saham.

Transfer pricing tidak lepas dari mengurangi dan meminimalisir kendala antar negara dalam memperluas transaksi. Transaksi sesuai azas kewajaran dan kelaziman dapat terjadi apabila indikator yang independen (tidak

31 PENGARUH TUNNELLING INCENTIVE DAN DEBT CONVENANT TERHADAP TRANSFER PRICING YANG DIMODERASI OLEH TAX MINIMIZATION

Astuti Mintorogo

Syahril Djaddang

Universitas Pancasila 
ada hubungan istimewa) harga yang berlaku berlandaskan kekuatan pasar (hukum permintaan dan penawaran). Transaksi dengan pihak hubungan istimewa terjadi harga yang berlaku menjadi tidak sesuai azas kewajaran dan kelaziman (arm's length principle) karena harga pasar tidak semestinya terjadi.

Tax minimization pada umunnya menggeserkan biaya maupun penghasilan perusahaan yang terkait

\section{TINJAUAN PUSTAKA DAN PENGEMBANGAN HIPOTESIS}

Tunneling didefinisikan sebagai suatu perilaku pemegang saham mayoritas memprioritaskan kepentingan pribadi melalui transfer assets atau profit perusahaan, akan tetapi biaya ditanggungjawabkan kepada shareholders minoritas Tunneling dapat terjadi melalui strategi merger dan akuisisi oleh pemilik saham mayoritas terhadap minoritas.

Transfer pricing didefinisikan
sebagai pertukaran antardisidional dengan transaksi perihal related party atau dengan lawan transaksi yang memiliki tarif pajak lebih berbeda atau lebih rendah. Selain tax minimization, kepemilikan saham mempengaruhi ketetapan dalam menjalankan transfer pricing. Struktur kepemilikan di indonesia lebih sedikit jumlah pemilik yang memungkinkan terjadinya kontradiksi keagenan (agency theory) antara mayoritas dan minoritas shareholders.

perihal harga jual khusus guna mencatat biaya bagi divisi pembeli (buy division) dan pendapatan bagi divisi penjual (selling division).

$$
\text { Debt covenant juga }
$$

mempengaruhi keputusan perusahaan melakukan transfer pricing. The debt covenant hypothesis perusahaan yang memiliki rasio hutang yang tinggi lebih memilih untuk melakukan kebijakan akuntansi yang membuat laba perusahaan menjadi semakin tinggi dan salah satu praktek perubahan laba adalah dengan tranfer pricing.

\section{Model Penelitian}

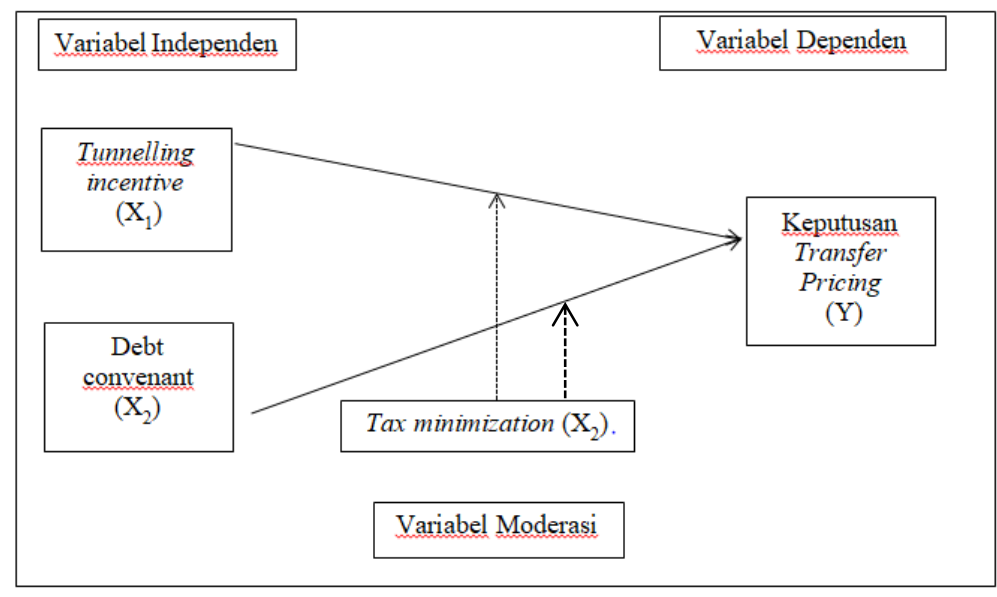

Pengaruh tunnelling incentive terhadap keputusan transfer pricing

Keputusan melakukan transfer pricing dapat dipengaruhi oleh kepemilikan saham. Yuniasih et al,
(2012) "mengungkapkan bahwa tunneling incentive berpengaruh positif pada ketetapan transfer pricing", kondisi dimana terpusatnya kepemilikan saham perusahaan publik di Indonesia 
sehingga tindakan tunnelling cenderung dilakukan oleh shareholders mayoritas. Maka dikembangkan hipotesis sebagai berikut:

$\mathrm{H}_{1}$ : Tunneling incentive berpengaruh terhadap keputusan transfer pricing

Pengaruh debt convenant terhadap keputusan transfer pricing

Salah satu cara transfer pricing adalah pemilihan prosedur akuntasi melalui laporan perubahan laba periode berikutnya ke periode sekarang. Richardson. et. al. (2013) menyatakan bahwa debt convenant mempunyai positif dengan keputusan

perusahaan dalam menjalankan transfer pricing.

$\mathrm{H}_{2}$ : Debt convenant berpengaruh terhadap keputusan transfer pricing

Pengaruh tax minimization memoderasi tunnelling incentive terhadap keputusan transfer pricing

Tax minimization merupakan tindakan yang diambil oleh perusahaan agar mengurangi beban pajak perusahaan. Dengan stimulus dapat mengurangi beban pajak akan memperkuat hubungan tunneling incentives dengan transfer pricing (Nuradila \& Wibowo, 2018).

$\mathrm{H}_{3}$ : Tax minimization dapat memoderasi pengaruh Tunneling incentive terhadap keputusan transfer pricing.

Pengaruh tax minimization memoderasi debt convenant terhadap keputusan transfer pricing

Angka hutang yang tinggi dapat ditimbulkan oleh pimpinan untuk meningkatkan laba perusahaan dengan menggunakan transfer pricing. Hutang perusahaan digunakan untuk mengecilkan biaya pajak perusahaan (tax minimization) dengan meningkatkan anggaran bunga sehingga laba perusahaan dapat meningkat (Nuradila \& Wibowo, 2018).

$\mathrm{H}_{4}$ : Tax minimization dapat memoderasi pengaruh Debt convenant terhadap keputusan Transfer pricing

\section{METODE PENELITIAN}

Penelitian berasal dari laporan keuangan perusahaan, pada unit analisis industri manufaktur tekstil yang tercatat dalam Bursa Efek Indonesia dengan horizon waktu sejak tahun 2015 sampai 2018.

\section{Populasi dan Sampel}

Objek yang digunakan perusahaan manufaktur tekstil yang tercatat di Bursa Efek Indonesia tahun 2015-2018. Pengambilan sampel dilakukan dengan metode purposive sampling. Kriteria sampel perusahaan multinasional sektor manufaktur yang tercatat di BEI periode 2015-2018. Perusahaan yang melaporkan Laporan Keuangan Bursa Efek Indonesia dalam periode 2015-2018 dan tidak mengalami kerugian dan menggunakan mata uang rupiah (IDR). Kepemilikan asing 20\% atau lebih.

\section{Metode Analisis Data}

Analisis regresi data panel ialah alat statistika untuk menguji penggabungan data antara data cross section dan data time series dimana unit cross section yang sama diukur dengan waktu yang berbeda. Regresi panel pada penelitian ini, dirumuskan dalam persamaan:

$\mathrm{TP}=\alpha+\beta 1 \mathrm{TI}+\beta 2 \mathrm{DEBT}+\beta 3 \mathrm{TI}$.TMIN $+\beta 4$ DEBT.TMIN $+\beta 5$ BONUS $+\beta 6$ $\mathrm{ROE}+\beta 7$ AUD_EKS $+\beta 8 \mathrm{RPT}+\beta 9$ $\mathrm{SIZE}+\varepsilon$ 
Keterangan:

$\mathrm{TP}=$ transfer pricing, $\mathrm{TI}=$ Tunnelling Incentive , DEBT $=$ Debt

convenant ;MIN = Tax Minimization; $\mathrm{BON}=$ Bonus Mechanism; $\mathrm{ROE}=$ Return of Equity; AUD_EKS = Auditor Eksternal; RPT = Related Party
Transactions; SIZE = Firm Size.

Pengukuran Variabel

Transfer pricing

Diukur dengan nilai Related Party Transaction (RPT) dalam (Nuradila \& Wibowo, 2018).
Nilai Related Party

Transaction

\section{Tunnelling Incentive}

Diukur dengan pada persentase kepemiikan saham yang melebihi $20 \%$. Hal ini harus sesuai dengan "Undang-
Piutang Related Party Transaction $\mathrm{X}$ Total Piutang $100 \%$

\section{Debt convenant}

Diukur dengan indeks trend laba bersih (ITRENDLB) dalam (Nuradila \& Wibowo, 2018)

$$
\text { Debt Equity Ratio }=\frac{\text { Total Debt }}{\text { Total Equity }} \times 100 \%
$$

\section{Tax minimization}

Diukur dengan effective tax rate / ETR :

(Nuradila \& Wibowo, 2018)

$$
\text { Effective Tax Rate }=\frac{\text { Tax Expense }}{\text { Laba Kena Pajak }} \times 100 \%
$$

Keterangan:

Variabel Kontrol dalam penelitian in diantaranya: Mekanisme bonus, Return on Equity, The Auditor Quality, Related Party Sales, Firm Size.

\section{Mekanisme Bonus}

Merupakan salah satu metode perhitungan akuntansi dalam rangka meningkatkan pendapatan bonus oleh pimpinan melalui peningkatan laba 
perusahaan secara global atau (Hartati et al., 2015)

keseluruhan :

Bonus

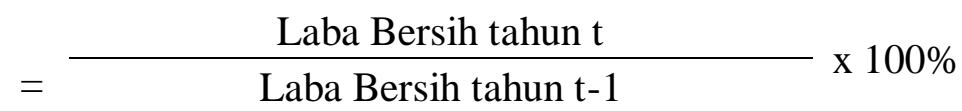

Return on Equiy

Diukur untuk mengontrol kemungkinan efek dari profitabilitas perusahaan pada ketetapan penentuan harga transfer, Lo et al (2010).

$$
\text { Return of Equity }=\frac{\text { Net Income }}{\text { Total Equity }} \times 100 \%
$$

Related Party Transcation

Jika RPT adalah tinggi, ini mungkin menunjukkan pelanggan RPT akan memiliki kekuatan tawar yang kuat dan mengarah ke yang lebih rendah rasio laba kotor (Lo et al., 2010).

$$
\begin{gathered}
\text { Related Party } \\
\text { Transaction }
\end{gathered} \quad=\frac{\text { Amount of Related Party Transaction }}{\text { Total sales }} \times 100 \%
$$

\section{Kualitas Audit}

Kualitas audit berkaitan erat dengan koefisien respon laba masa depan (FERC) karena informatifan laba laporan keuangan yang teraudit lebih baik daripada laporan keuangan tidak teraudit. Kualitas audit dapat meningkatkan kredibilitas dari informasi laporan keuangan (Murwaningsari, 2014).

\section{Ukuran Perusahaan atau Firm Size}

Diukur dengan penjualan pihak terkait atas penjualan kepada lima pelanggan terbesar perusahaan, dapat menggunakan LN dari total assets (Lo et al., 2010).

\section{HASIL DAN PEMBAHASAN}

Penelitian ini menggunakan analisis regresi panel. Pengujian Parameter ini: Uji Chow

Uji chow adalah pengujian
yang pertama dilakukan dalam
menganalisis model estimasi yang akan
diperlukan dalam pemilihan model
common effect atau fixed effect. Nilai uji
chow dapat dilihat dari nilai Prob.
"Cross-section Chi-square"

\section{Tabel 1}

Hasil Uji Chow

\begin{tabular}{lcll}
\hline Metode & Prob. Chi Square & Keputusan & Keterangan \\
\hline Uji Chow & $0,00<0,05$ & Ha diterima & Fi ed Effect Model \\
\hline
\end{tabular}



Dari hasil uji Chow menunjukkan nilai lebih kecil dari 0,05 maka dapat dinyatakan bahwa model yang terpilih adalah Fixed Effect Model.

\section{Uji Hausman}

Pengujian kedua yaitu uji Hausman untuk memilih antara Fixed Effect Model atau Random Model

Tabel 2

Hasil Uji Hausman

\begin{tabular}{lccl}
\hline Metode & Prob. Chi Square & Keputusan & Keterangan \\
\hline Uji Hausman & $0,00<0,05$ & Ha diterima & Fi ed Effect Model \\
\hline
\end{tabular}

Dari hasil uji Chow menunjukkan nilai lebih kecil dari 0,05 maka dapat dinyatakan bahwa model yang terpilih adalah Fixed Effect Model.

Uji Kofisien Determinasi

Uji koefisien determinasi $\left(\mathrm{R}^{2}\right)$ bertujuan menguji variabel terikat (respons) dijelaskan oleh variabel prediktor dengan melihat besarnya nilai Adjusted R2 "Nilai koefisien determinasi $\left(\mathrm{R}^{2}\right)$ berada di antara $0 \mathrm{~s} / \mathrm{d} 1$ sehingga semakin meningkat nilai Adjusted $\mathrm{R}^{2}$, maka tinggi juga kemampuan variabel independen dalam menjelaskan variabel dependen.

Tabel 3

Hasil Uji Koefisien Determinasi

\begin{tabular}{lc}
\hline R-Squared & Adjusted R Squared \\
\hline 0,99 & 0,98 \\
\hline
\end{tabular}

Uji Koefisien diperoleh nilai Adjusted $\mathrm{R}^{2}$ sebesar 0,98 "berarti seluruh variabel independen mampu menjelaskan variasi dari variabel dependen sebesar 98\%", sedangkan sisanya sebesar $2 \%$ dapat dilihat dengan faktor lain yang tidak ada model.

\section{Uji Signifikansi Koefisien Regresi Serentak (F-test)}

Uji signifikansi koefisien regresi serentak (F-test) bertujuan untuk menguji seberapa besarnya pengaruh variabel prediktor yang terdapat pada model regresi terhadap variabel terikatnya (respons).

Tabel 4

Hasil Uji F-Test

\begin{tabular}{lccrr}
\hline Model & Regresi & F Statsistik & Prob F Statistik & Keterangan \\
\hline Regresi & Balance Panel & 123,47 & 0,00 & berpengaruh \\
\hline
\end{tabular}

Nilai F-statistic sebesar 123,45 dengan nilai prob. (F-statistic) yaitu 0,00 $<$ alpha 0,05 dapat diartikan bahwa sekiat serentak seluruh variabel independen yaitu tunneling incentive dan debt convenant dengan tax minimization sebagai pemoderasi memiliki pengaruh terhadap transfer pricing. Apabila angka signifikansi dari $\mathrm{F}$ lebih rendah dari angka kepercayaan 0,05 maka variabel independen menggambarkan variable dependen yang berpengaruh.

\section{Uji Signifikansi Koefisien Regresi Parsial (T-test)}


Uji signifikansi koefisien regresi parsial (T-test) dilakukan untuk mengetahui arah hubungan serta ada atau tidak pengaruh masing-masing variable independen terhadap variabel dependen.

Tabel 5

Hasil Uji Parsial (T-Test)

\begin{tabular}{lllll}
\hline Variabel & Prediksi & Koefisien & Prob. & Kesimpulan \\
\hline TI & Berpengaruh & 0,050 & 0,029 & Berpengaruh \\
\hline DEBT & Berpengaruh & $-0,001$ & 0,001 & tidak berpengaruh \\
\hline TI_TMIN & Berpengaruh & $-0,105$ & 0,778 & tidak berpengaruh \\
\hline DEBT_TMIN & Berpengaruh & $-0,009$ & 0,981 & tidak berpengaruh \\
\hline BONUS & Berpengaruh & 0,002 & 8,878 & tidak berpengaruh \\
\hline ROE & Berpengaruh & 0,032 & 0,717 & tidak berpengaruh \\
\hline AUD_EKS & Berpengaruh & 0,046 & 0,424 & tidak berpengaruh \\
\hline RPT & Berpengaruh & 0,040 & 0,9062 & tidak berpengaruh \\
\hline SIZE & Berpengaruh & $-0,206$ & 0,144 & tidak berpengaruh \\
\hline C & Berpengaruh & & & tidak berpengaruh \\
\hline
\end{tabular}

\section{Sumber Data Tahun 2015-2018.}

Notes: $\mathrm{TI}=$ Tunnelling Incentive $; \mathrm{DEBT}=$ Debt convenant $; \mathrm{TMIN}=$ Tax

Minimization; BONUS = Mekanisme Bonus; ROE = Return of Equity;

AUD_EKS = Auditor Eksternal; RPT= Related Party Transactions;

SIZE = Firm Size .

Hasil pengujian dari masing-masing variabel independen meliputi :

$\mathrm{H}_{1}$ menyatakan tunnelling berpengaruh terhadap transfer pricing. Hasil pengujian dalam penelitian ini sejalan dengan penelitian Yuniasih et. al., (2012) menjelaskan bahwa tunnelling incentive berpengaruh pada keputusan transfer pricing. Hal ini konsisten pada hipotesis yang diajukan. Kondisi langka kepemilikan saham pada perusahaan publik di Indonesia cenderung terpusat, hingga terjadi kemiripan shareholders kebanyakan agar menjalankan tunneling. $\mathrm{H}_{1}$ diterima

$\mathrm{H}_{2}$ menyatakan tunnelling berpengaruh terhadap transfer pricing. Hasil pengujian dalam penelitian ini menyatakan bahwa debt convenant tidak berpengaruh terhadap transfer pricing sehingga $\mathrm{H}_{2}$ ditolak. Sari \& Mubarok
(2018) menyatakan debt convenant tidak berpengaruh dan Hipotesis yang diajukan tidak sesuai. Resiko kekurangan dalam memenuhi kewajiban membayar hutang bagi perusahaan dapat ditingkatkan dengan angka utang yang tinggi. Dimungkinkan adanya kenaikkan biaya bunga dan kenaikan biaya pajak, di mana alokasi hutang perusahaan diperuntukkan bagi keperluan investasi.

$\mathrm{H}_{3}$ menyatakan tax minimization dapat memoderasi pengaruh tunnelling incentive memiliki pengaruh terhadap transfer pricing. Hasil pengujian penelitian ini menyatakan bahwa debt convenant tidak berpengaruh terhadap transfer pricing sehingga $\mathrm{Ha}_{3}$ ditolak. Yuniasih et al., (2012), tax minimization memoderasi secara signifikan pengaruh tunnelling incentive terhadap keputusan 
transfer pricing pada perusahaan multinasional.

$\mathrm{H}_{4}$ menyatakan tax minimization dapat memoderasi pengaruh debt convenant terhadap transfer pricing. Hasil pengujian dalam penelitian ini menyatakan bahwa debt convenant tidak berpengaruh terhadap transfer pricing sehingga $\mathrm{H}_{4}$ ditolak. Hasil pengujian dalam penelitian ini sejalan akan tetapi signifikasi yang berbeda dengan penelitian yang dilakukan (Nuradila \& Wibowo, 2018). Ketika perusahaan memiliki tingkat leverage tinggi maka kecenderungan perusahaan dalam menjalankan transfer.

Bonus tidak berpengaruh terhadap keputusan transfer pricing. Lo et. al., (2010) memberi pernyataan mengenai bonus plan tidak mempunyai pengaruh pada ketetapan transfer pricing. Biaya pembayaran bonus dari rumusan profitabilitas mempunyai pengaruh terhadap ketetapan transfer pricing. Untuk memberikan bonus kepada direksi, pemilik perusahaan akan memantau hasil kerja direksi dalam mengelola perusahaanya.

Return On Equity (ROE) tidak bepengaruh kepada keputusan transfer pricing. Hal ini sesuai dengan penelitian Richardson et al., (2013) yang menyatakan bahwa perusahaan yang mengalami pendapatan besar akan seiring dengan sumber pendanaan dalam yang lebih besar sehingga penggunaan modal internal diutamakan.

Auditor Eksternal (Aud_Eks) tidak berpengaruh pada keputusan transfer pricing. Penelitian ini sejalan dengan Lo et al., (2010) menyatakan bahwa kualitas auditor tidak berpengaruh signifikan.

Related Party Transactions (RPT) tidak berpengaruh pada keputusan transfer pricing. Sejalan dengan Lo. et al., (2010) menyatakan bahwa kualitas auditor tidak berpengaruh signifikan. Diukur dengan jumlah pihak terkait penjualan dari total penjualan. Jika RPT adalah tinggi, ini mungkinmenunjukkan pelanggan RPT akan memiliki kekuatan tawar yang kuat dan mengarah ke yang lebih rendah rasio laba kotor.

Firm Size (Size) tidak berpengaruh pada keputusan transfer pricing. Penelitian ini sejalan dengan Lo et al., (2010) menyatakan bahwa firm size tidak berpengaruh signifikan negatif. Penelitian ini tidak sejalan dengan Richardson et al., (2013) sehingga didukung oleh hasil perusahaan yang lebih besar masuk dalam memanipulasi harga transfer yang lebih tinggi. Jadi suatu perusahaan bisa dikatakan perusahaan besar, jika aset yang dimilikinya juga besar.

\section{KESIMPULAN DAN SARAN}

Hasil kesimpulan yang diperoleh adalah Tunneling incentive dan Debt convenant terhadap keputusan Transfer pricing. Tunnelling incentive berpengaruh terhadap keputusan transfer pricing sedangkan debt convenant tidak berpengaruh terhadap keputusan transfer pricing. Tax minimization tidak dapat memoderasi pengaruh antara tunnelling incentive dan debt convenant terhadap keputusan transfer pricing. Bonus tidak berpengaruh pada keputusan keputusan transfer pricing. Return on Equity (ROE) tidak berpengaruh pada keputusan transfer pricing. Auditor Eksternal (Aud_Eks) tidak berpengaruh terhadap keputusan transfer pricing. Related Party Transactions (RPT) tidak berpengaruh terhadap keputusan transfer pricing. Firm Size (Size) tidak berpengaruh terhadap keputusan transfer pricing. Penelitian ini berbasis data sekunder. Sampel yang digunakan perusahaan manufaktur yang tercatat di Bursa Efek Indonesia pada tahun 2015- 
2018, dan hanya menguji tunnelling incentive dan debt convenant.

Metode Special Purpose Vehicle (SPV) dalam praktek Transfer Pricing banyak terjadi di negara Asia. Memperbanyak sampel negara-negara Asia dapat lebih mengembangkan penelitian lebih lanjut. Disarankan juga bagi para investor yang ingin berinvestasi, sebaiknya melakukan pengecekan ulang laporan pada keuangan yang ditebitkan oleh perusahaan, pada saat mengambil keputusan untuk berinvestasi.

\section{DAFTAR PUSTAKA}

Hartati, W., Desmiyawati, \& Julita. (2015). Tax Minimization, Tunneling Incentive dan Mekanisme Bonus Terhadap Keputusan Transfer Pricing Seluruh Perusahaan yang Listing di Bursa Efek Indonesia. Proceding SNA XVIII, 241-246. https://doi.org/10.1109/PAPCO N.2001.952974

Johnson, S., LaPorta, R., \& Lopes-DeSilannes, F. (2000). Tunneling. American Economic Review Papers and Proceedings, 90(20), 22-27.

Klassen, K., Lisowsky, P., \& Mescall, D. (2017). Transfer Pricing : Strategies, Practices, and Tax Minimization. Contemporary Accounting Research, 34(1), 455-493.

https://doi.org/10.1111/19113846.12238

Lingga, I. S. (2012). Aspek Perpajakan dalam Transfer Pricing dan Problematika Praktik Penghindaran Pajak (Tax Avoidance). Zenit, 1(3), 209220.

Lo, A. W. Y., Wong, R. M. K., \& Firth, M. (2010). Tax, Financial Reporting, and Tunneling Incentives for Income Shifting: An Empirical Analysis of the Transfer Pricing Behavior of Chinese-Listed Companies. Amarican Acounting Association, 32(2), 1-26. https://doi.org/10.2308/jata.2010 .32.2.1

Mangoting, Y. (2000). Aspek Perpajakan Dalam Praktek Transfer Pricing. Jurnal Akuntansi \& Keuangan, 2(1), 69-82. Murwaningsari, E. (2014). Kepemilikan Institusional Dan Kualitas Audit Future Earnings Response Coefficient. Jurnal Keuangan Dan Perbankan, Vol.18, No.2 Mei 2014, 18(2), 161-171.

Mutamimah. (2009). Tunneling Atau Value Added Dalam Strategi Merger Akuisisi Di Indonesia. Jurnal Manajemen Teori Dan Terapan, 2(2), 161-182.

Nuradila, R. F., \& Wibowo, R. A. (2018). Journal of Islamic Finance and Accounting. Tax Minimization Sebagai Pemoderasi Hubungan Antara Tunneling Incentive, Bonus Mechanism Dan Debt Convenant Dengan Keputusan Transfer Pricing, 1(1), 63-76.

Rachmawati, S. (2008). Pengaruh Faktor Internal dan Eksternal Perusahaan Terhadap Audit Delay dan Timeliness. Jurnal Akuntansi Dan Keuangan,10(1), $1-10$. https://doi.org/10.9744/jak.10.1. pp. $1-10$

Rahayu, N. (2010). Evaluasi Regulasi Atas Praktik Penghindaran Pajak Penanaman Modal Asing. Jurnal 
Akuntansi Dan Keuangan

Indonesia, 7(1), 61-78.

https://doi.org/10.2466/pr0.1982

.51.3f. 1111

Republik Indonesia, Undang-Undang Nomor 36 Tahun 2008 tentang tentang Penerapan Prinsip Kewajaran dam Kelaziman Usaha dalam Transaksi Antara Wajib Pajak dengan Pihak yang Mempunyai Hubungan Istimewa.

Richardson, G., Taylor, G., \& Lanis, R. (2013). Deteminant of Transfer Pricing Aggressiveness: Empirical Evidence From Austrakua Firm. Journal of Contemporary Accounting and Economics, 9(2), 136-150.

Sari, E. P., \& Mubarok, A. (2018). Pengaruh Profitabilitas, Pajak dan Debt Convenant Terhadap Transfer Pricing (Studi Empiris
Perubahan Keempat UndangUndang Nomor 7 Tahun 1983 tentang Pajak Penghasilan Republik Indonesia, UndangUndang Nomor 32/PJ/2011

Perusahaan Manufaktur Terdaftar di BEI Tahun 20122016). Proceding Seminar Akuntansi, 1(1), 1-6.

Suandy, E. (2011). Hukum pajak Edisi 5. Salemba Empat.

Yuniasih, N. W., Rasmini, N. K., \& Wirakusuma, M. G. (2012). Pengaruh Pajak Dan Tunneling Incentive Pada Keputusan Transfer Pricing Perusahan Manufaktur Yang Listing DI Bursa Efek Indonesia. In Journal and Proceedings of SNAAccounting National Symposium (Vol. 15, pp. 1-23). 
Jurnal Akuntansi dan Auditing

Volume 16/No. 1 Tahun 2019 : 30-40 